\title{
Preservation of Renal Function in Chronic Renal Failure
}

\author{
Judith A. Whitworth*, Benno U. Ihle, Gavin J. \\ Becker and Priscilla S. Kincaid-Smith \\ Department of Nephrology, Royal Melbourne Hospital \\ Victoria 3050, and * School of Medicine, St George Hospital, \\ University of New South Wales, Kogarah 2217, New South \\ Wales, Australia
}

Whitworth, J.A., Ihle, B.U., Becker, G.J. and Kincaid-Smith, P.S. Preservation of Renal Function in Chronic Renal Failure. Tohoku J. Exp. Med., 1992, 166 (1), 165-183 — Mechanisms of progression of chronic renal failure $(\mathrm{CRF})$ have been well documented in the rat but may not be relevant in man. Factors which may modify clinical CRF include underlying disease, diet, hypertension, intercurrent events, and adverse or beneficial effects of drug therapy. It has been argued that progression in many forms of renal disease is inexorable below a certain level of renal function. In other diseases, eg primary malignant hypertension, analgesic nephropathy, function frequently improves in both the short and long term with appropriate management. Thus knowledge of the nature of the underlying disease is essential in assessing progression. The value of diet in preserving renal function has been debated, particularly the relative roles of protein and phosphate control. In our own unit, a prospective randomized study showed a benefit of protein restriction. Development of accelerated hypertension is an important cause of progression of renal disease and clinical and experimental evidence supports the view that non-accelerated hypertension is also a factor in progression, amenable to treatment. Various intercurrent events may accelerate progression and function may be lost permanently following sepsis, urinary tract obstruction, renal arterial or venous obstruction, hypotension and in some cases pregnancy. Numerous drugs can have deleterious effects on the kidney. The possibility that converting enzyme inhibitors might preserve renal function is attracting attention but in view of their side effects their place in therapy should be determined by prospective controlled studies in which the above factors are carefully considered.— chronic renal failure; converting enzyme inhibitors ; diet; hypertension; protein restriction.

\section{"The proper study of mankind is man" - Alexander Pope}

Studies in animals have underpinned many, if not most, of our advances both in understanding the nature of disease and in clinical therapeutics.

This notwithstanding, it is clearly not always possible to extrapolate from animals to man, and studies of preservation of renal function in chronic renal

Author for correspondence: Prof. J.A. Whitworth, School of Medicine, St George Hospital, Kogarah 2217, NSW Australia. 
failure are a case in point (Brenner 1983). Fine (1988) has recently reviewed the natural history of experimental and clinical renal disease in man, dog, rabbit and rat and pointed out the considerable species variation. Certainly the progressive glomerulosclerosis seen in relation to hyperfiltration in the rat is not common in human subjects who have lost a kidney in childhood, even in the long term (Robitaille et al. 1985) or in living related renal donors (Ogden 1983).

In the light of these difficulties, this paper will concentrate on the problem confronting clinicians : preservation of renal function in patients with chronic renal disease.

The scope of the problem of chronic renal failure (CRF) is well recognized. The success of dialysis/transplantation as modes of treatment is unquestionable, but in many countries their cost is a major concern.

The Australian data (Disney 1987) are based on a 100\% return rate and thus provide very accurate information. Data from Europe (EDTA Registry Centre Survey 1985, 1987) and the United States (Eggers 1988) are not as comprehensive, given the much larger populations. Table 1 shows the acceptance rates in 1985 for new patients in these countries and Table 2 shows the total numbers of patients treated by end-stage renal failure (ESRF) programs in 1985. In the United States (Eggers 1988), the cost of the Medicare ESRF program was $\$$ US 1 billion in 1979, \$US 2 billion in 1984, and was projected to reach \$US 3 billion in 1989 . It follows then that preservation of renal function in patients with chronic renal disease is a financial as well as a medical priority.

\section{Mathematical models of progression of renal failure}

Many patients with renal functional impairment suffer relentless progression, and in individual patients mathematical models have been applied to plot and predict the course. The most commonly used is a plot of the reciprocal of the plasma creatinine concentration - a concept independently introduced by Mitch et

TABLE 1. New patients accepted onto renal replacement therapy in 1985

\begin{tabular}{lcccc}
\hline \multicolumn{1}{c}{ Region } & Reference & Center response & New patients & Per million \\
\hline Australia & $(31)$ & $100 \%$ & 616 & 39 \\
Europe & $(33)$ & $70.6 \%$ & 21195 & 34.2 \\
USA & $(34)$ & Medicare & 28944 & 122 \\
\hline
\end{tabular}

TABLE 2. Patients alive on renal replacement therapy in 1985

\begin{tabular}{lccc}
\hline \multicolumn{1}{c}{ Region } & Reference & Patients & Par million \\
\hline Australia & $(31)$ & 4338 & 275 \\
Europe & $(33)$ & 109125 & 176 \\
USA & $(34)$ & 112641 & 475 \\
\hline
\end{tabular}


al. (1976) and Rutherford and his colleagues (1977). The concept is based on the observation that in a given patient the plasma creatinine varies inversely with creatinine clearance (Cockcroft and Gault 1976), with corrections for age, weight and sex. Cockcroft and Gault (1976) pointed out the limitations in prediction of creatinine clearance from plasma creatinine concentrations, including a requirement for a steady state, variations in the relationship between muscle mass and total body weight and the problems related to the use of creatinine determinations to measure renal function (tubular secretion, diurnal variation, non-creatinine chromogens and alterations in creatinine production with increasing renal failure). Many of these limitations are reduced when using serial observations in a given patient, but on occasions can have a profound influence on the relationships between plasma creatinine, creatinine clearance and renal function, vitiating attempts to plot or predict a steady course.

Rutherford et al. (1977) studied the course in 63 patients with diverse causes of renal failure. Although most patients seemed to pursue a steady course, with a single straight line relationship between $1 / \mathrm{Cr}$ and time, almost $20 \%$ of patients did not, and required the construction of 2 or more lines, implying an alteration in the slope at some point in their course. This occurred in 3 of 6 patients with glomerulonephritis, 2 of 8 with diabetes, 1 of 8 with pyelonephritis and 1 of 7 with polycystic disease. They also showed that to form lines of fit of the logarithm of plasma creatinine against time even more often required the construction of two or more lines. The conclusion can be drawn that in many patients definite changes in course appear with either acceleration or slowing of the rate of progression.

\section{Nature of the underlying disease}

Variations in rate of progression can be shown between different diseases, patients with the same disease, and individual patients at different times.

Using the rate of rise in the reciprocal of s. creatinine in $\mathrm{dl} / \mathrm{mg} / \mathrm{month}$, Rutherford and co-workers (1977) reported similar progression in glomerulonephritis (0.014), diabetes (0.019) and polycystic kidneys (0.017) but not chronic pyelonephritis (0.005). Oldrizzi et al. (1985) found similar rates in glomerulonephritis (0.019) and polycystic disease (0.019) and again a slower course in pyelonephritis (0.003). However, patients on a protein restricted diet showed quite different rates, glomerulonephritis 0.017 , polycystic kidney 0.003 and pyelonephritis 0.0002 .

In different patients with the same disease, considerable variations are seen. In the series of Rutherford and colleagues (1977), rates varied as follows : glomerulonephritis $0.007-0.026$, diabetes $0.003-0.038$, polycystic kidneys $0.0015-0.063$, and pyelonephritis 0.000-0.014. The study (Rutherford et al. 1977) also showed great variation from time to time in individual patients, with variations of over 10-fold. 
Among the glomerular diseases particularly characterized by remission and exacerbation (often due to superadded crescent formation) with fluctuations in renal function are IgA nephropathy, membranoproliferative glomerulonephritis, lupus nephritis and the vasculitides. Associated increases in proteinuria and haematuria are usual (Kincaid-Smith and Whitworth 1987).

In polycystic kidney disease sudden decline in function, often with loin pain, haematuria or other urinary symptoms, suggests haemorrhage, infection or obstruction by cyst distention. The possibility that cyst de-roofing might help in specific cases has recently been raised (Bennett et al. 1987) despite previous reports that Rovsing's operation is more likely to accelerate renal failure (Mitcheson et al. 1977).

Analgesic nephropathy is one condition where removal of the cause i.e. cessation of all analgesics, and treatment of the complications usually leads to stabilization and even recovery of a great deal of lost function (Kincaid-Smith et al. 1970). Sudden decline in function in stable patients should prompt an aggressive search for non-steroidal inflammatory drug intake, obstruction due to papillary necrosis, urine infection, ureteral stenosis, renal papillary tumor or renal artery stenosis, all of which occur more frequently in these patients.

Although transient deterioration in function has been associated with sepsis, it has been difficult to clearly relate urine infection and chronic functional decline in adults with reflux nephropathy (Kunin 1985). However, scarring is clearly associated with urine infection in children. Persistence of reflux is also a factor which is relevant in the child but not the adult (El-Khatib et al. 1987). Ureteral obstruction by calculus is also a recognized complication of reflux nephropathy (Torres et al. 1983).

Currently there is little evidence that control of hyperglycemia will prevent progression of clinically apparent diabetic nephropathy (Viberti et al. 1983). Conversely acute deterioration in function is not caused by poor diabetic control, other than through pre-renal effects. If sudden deterioration in function occurs, urine infection with renal abscess formation, renal papillary necrosis and renal artery stenosis should be considered.

\section{Hypertension in progression of renal disease}

Does benign essential hypertension cause renal failure? The haemodynamic changes of essential hypertension are well known. Renal blood flow (RBF) decreases but filtration fraction (FF) increases and glomerular filtration is relatively well preserved (Birkenhager and Shalekamp 1976). There is a progressive fall in glomerular filtration rate (GFR) with age in normal subjects and this may be accelerated in hypertension. Reubi (1960) studied untreated patients with benign essential hypertension (DBP $<120 \mathrm{mmHg}$ ) and found only minor changes in renal haemodynamics, indistinguishable from aging changes. Even with DBP $120-150 \mathrm{mmHg}$, renal functional deterioration was minimal in the absence of 
grade III to IV retinopathy. However, whether or not benign essential hypertension causes renal failure progressing to end stage is a matter of some controversy.

Certainly essential hypertension complicated by malignant phase, or renal artery atheroma with severe renal ischaemia can cause end stage renal failure, but these are uncommon complications. In a recent analysis of 83 patients with accelerated hypertension we identified a cause for the hypertension in $80 \%$ of cases ( $\mathrm{Yu}$ et al. 1986).

If benign essential hypertension does cause ESRF, it must be a very rare event. Epidemiologic studies indicate that over $15 \%$ of the Australian population are hypertensive (Australian Therapeutic Trial in Mild Hypertension 1980), ie there are over 2 million hypertensives in the country. On the other hand, in total there are only 275 patients per million on ESRF programs (Disney 1987), i.e. 1 in 400 Australians, compared with the 1 in 6 who are hypertensive. As the cause of primary renal disease is known in the majority of ESRF patients (Disney 1987), it follows that only 1 in 2000 patients with essential hypertension might be going into ESRF. Certainly the major treatment trials in essential hypertension have all been characterized by a paucity of renal end-points. We have reviewed the evidence that benign essential hypertension does not cause progressive renal damage elsewhere (Kincaid-Smith and Whitworth 1987). In brief, in 131 consecutive autopsies on patients with $\mathrm{BP}>180 / 110 \mathrm{mmHg}$ but no retinal haemorrhages or exudates, there was no evidence of reduction in renal size and hyalinized glomeruli were rare. In a study of 10,000 autopsies, Zollinger (1966) found only 11 cases of renal shrinkage he could attribute to benign arteriosclerosis and 7 of these had severe renal artery atheroma.

It should be noted that studies attributing renal impairment to essential hypertension commonly fail to report urine microscopy findings, or use criteria for "normality" which are inappropriate ie $<10$ red blood cells/ hpf (Kesson et al. 1978 ; Birch et al. 1983; Lindeman et al. 1984), so that the "essential" group are likely to include patients with underlying renal parenchymal disease (Mowbray et al. 1980).

Hypertension complicating renal parenchymal disease. Most, if not all, forms of renal disease can lead to hypertension, particularly if renal impairment is present, but hypertension is more common in vasculitis and glomerulonephritis than in interstitial disease (Vendemia et al. 1981; Blythe 1985). Hypertension is a common mode of presentation of renal disease and should always prompt careful urine examination.

Hypertension is widely regarded as a poor prognostic feature in renal disease (Orofino et al. 1987) and there is both experimental (Neugarten et al. 1982; Okuda et al. 1983 ; Baldwin and Neugarten 1985 ; Blantz et al. 1987) and clinical evidence that benign hypertension accelerates progression of renal disease (Baldwin and Neugarten 1985; Shimamatsu et al. 1985). Certainly patients with renal disease who develop malignant hypertension usually progress very rapidly 
to end-stage. We have shown (Becker et al. 1986) that the course of functional decline in patients with reflux nephropathy who experience severe uncontrolled hypertension (DBP $>120 \mathrm{mmHg}$ but without haemorrhages or exudates) is more rapid than that of a cohort of patients with similarly impaired renal function (plasma creatinine 0.2-0.4 mmol/liter), whose blood pressure was well controlled. Treatment of hypertension has been reported to slow progression in diabetic nephropathy (Mogensen 1982 ; Parving et al. 1983) and some other forms of renal disease (Pohl et al. 1974 ; Baldwin and Neugarten 1985 ; Bergstorm et al. 1986).

\section{Extrinsic factors}

$A$ variety of extrinsic or non-renal factors can accelerate renal failure (Table 3). Shock, sepsis, dehydration, cardiac failure and other causes of decreased effective renal perfusion can all precipitate acute on chronic renal failure or acceleration of functional decline. Improvement in pre-renal status can correspondingly improve renal function i.e., rehydration of the dehydrated patient.

Renal artery stenosis, often accompanied by severe hypertension, is a reversible cause of accelerated function decline. Repair or revascularization can improve or stabilize severe renal failure (Morgan et al. 1974). The result depends on the quality of the kidney beyond the stenosis, and the presence of severe intrinsic disease indicates a likely poor result from renal artery surgery. Renal vein thrombosis usually occurs in association with nephrotic syndrome and most commonly presents with worsening of proteinuria and progression of renal failure (Llach et al. 1980).

Obstruction to urine flow can occur with few suggestive symptoms in patients with renal disease. Prostatomegaly must be excluded in all males. In analgesic nephropathy both papillary necrosis and ureteral stricture (MacGregor et al. 1973) can cause painless ureteral obstruction.

TABLE 3. Some extrinsic factors affecting progression of renal failure

Diet

Reduction in effective renal perfusion

Sepsis

Dehydration, hypotension

Salt depletion

Cardiac failure

Liver failure

Renal artery stenosis

Renal vein thrombosis

Drugs

Pregnancy

Obstruction to urine flow 
Pregnancy. Though the effect of pregnancy on renal disease is controversial, we and others (Mackay 1963 ; Kincaid-Smith et al. 1967; Bear 1976; Klockars et al. 1980 ; Becker et al. 1985, 1986 ; Hou et al. 1985) have observed rapid deterioration in renal function in pregnancy, particularly in patients with initially impaired renal function.

In patients with reflux nephropathy we reported an accelerated course in relationship to pregnancy (Becker et al. 1986). Furthermore we reviewed the reports of pregnancies in patients with renal failure (plasma creatinine $>0.20$ mmol/liter) due to chronic primary glomerular disease (Becker et al. 1985) and found that deterioration in renal function was usual. Similarly Hou et al. (1985) found, in 23 women with plasma creatinine concentration $>0.11 \mathrm{mmol} / \mathrm{liter}$, that 7 , all with plasma creatinine $>0.15 \mathrm{mmol} /$ liter, experienced a decline in renal function greater than expected from the natural history of the underlying disease.

The factors involved in this renal functional decline with pregnancy are unclear. It seems likely that acceleration of secondary focal glomerulosclerosis (FGS) plays a part. We have found a greater incidence of FGS in patients with IgA glomerulonephritis in relationship to pregnancy (Whitworth et al. 1982b), and FGS in several of our patients with reflux nephropathy who deteriorated in pregnancy (Becker et al. 1986). Taylor et al. have suggested that primary FGS is accelerated by pregnancy, while others have each suggested that pre-eclampsia itself may lead to FGS (Taylor et al. 1978; Kida et al. 1985).

Nephrotoxins. Numerous drugs are potentially nephrotoxic (Schrier and Gottschalk 1988), particularly if renal function impairment is already present. In this context their nephrotoxic effects can easily be mistaken for the natural history of the disease (Table 4).

The potential danger of radiocontrast nephrotoxicity in patients with established renal dysfunction is well known (Schwartz et al. 1963). The more insidious syndrome of cholesterol embolization of the kidney should be considered in patients in whom acceleration of renal decline, often associated with microscopic haematuria, is seen after arterial catheter studies (Harrington et al. 1968).

TABLE 4. Some drugs commonly implicated in acceleration of renal failure

Radiocontrast agents

Aminoglycoside antibiotics

Nonsteroidal anti-inflammatory drugs

Angiotensin-converting enzyme inhibitors

Vitamin D supplements

Tetracyclines

Diuretics

Allopurinol 
Aminoglycoside antibiotics are both renally excreted and directly nephrotoxic so that the likelihood of these drugs causing acceleration of failure in patients with renal disease is high. The nephrotoxic effects of non-steroidal antiinflammatory drugs have been highlighted in the last few years (Clive and Stott 1984). Decrease in function is more likely if renal perfusion is compromised or salt-depletion is present. Early suggestions that sulindac, a drug which is not excreted in the urine in its active form, would not have this effect, do not seem to be borne out by clinical experience and we have seen acute renal failure associated with use of this drug (De Crespigny et al. 1988). Widespread use of allopurinol for hyperuricemia and gout has lead to recognition of a life-threatening allergic reaction, characterized by rash, hepatitis and worsening renal function (Hande et al. 1984).

\section{Diet in progression of $C R F$}

The use of low protein diets in management of CRF dates back to the early part of this century (for review see Klahr et al. 1983; Bergstrom 1984). For many years protein restriction was used to control uremic symptoms and its value in retarding progression was espoused only by a few enthusiasts. In recent years a number of studies, albeit methodologically unsatisfactory, have reported benefit of protein restriction in slowing progression of CRF (Maschio et al. 1987).

We have recently published an 18 month prospective randomized study of moderate protein restriction in 72 patients with renal insufficiency (p. creatinine 0.35-1.00 mmol/liter) (Ihle et al. 1989). Patients were observed for at least 3 months prior to entry to ensure that renal failure was progressive but not deteriorating acutely and only patients in whom hypertension, infection, and calcium/ phosphate balance were controlled were included. Patients with systemic disease eg diabetes, systemic lupus erythematosus, and those receiving immunosuppressives, converting enzyme inhibitors, or potentially nephrotoxic drugs were excluded.

After written informed consent was obtained, patients were randomized to ad libitum diet, containing a minimum of $0.75 \mathrm{~g}$ protein $/ \mathrm{kg} /$ day, or a $0.4 \mathrm{~g}$ protein/ $\mathrm{kg}$ /day diet containing at least $75 \%$ of high biologic value protein and caloric supplements to provide a minimum of $35 \mathrm{kcal} / \mathrm{kg} /$ day, so that the two diets were isocaloric. The low protein diet contained $700 \mathrm{mg} /$ day phosphorus, about $60 \%$ of the regular diet.

All patients were evaluated monthly by a dietician and clinician. Adequacy of the diet was monitored by body weight, anthropomorphics, diet history, s. albumin, transferrin, complement and whole blood lymphocyte counts.

Seventy-two patients were enrolled. Three withdrew because they found the diet unacceptable and 5 were excluded because of non-compliance with diet or medication, leaving 64 patients who completed the study. They comprised 42 men and 22 women, median age 37 (19-69 years), 33 on regular diet and 31 on low 
protein diet. The primary renal disease was similar in both groups (glomerulonephritis 15 and 13, polycystic kidney 5 and 7, reflux nephropathy 5 and 4, analgesic nephropathy 4 and 5 and miscellaneous 2 and 4 in low and regular protein groups, respectively).

Nine of 33 on regular diet reached ESRF and commenced dialysis during the study, compared with 2 of 31 on protein restriction $(p<0.05$, Chi squared test). GFR, as measured by ${ }^{51} \mathrm{Cr}$ EDTA clearance, was similar pre-treatment, $15 \pm 2 \mathrm{ml}$ / min in the regular diet patients and $14 \pm 3 \mathrm{ml} / \mathrm{min}$ in the low protein group. Final GFR was $6 \pm 3$ and $12 \pm 3 \mathrm{ml} / \mathrm{min}$ respectively, $(p<0.02$, Wilcoxon rank sum test), a $60 \%$ reduction on regular diet compared with only $17 \%$ in the low protein group. P. creatinine rose from $0.61 \pm 0.18$ to $0.93 \pm 0.25 \mathrm{mmol} /$ liter on regular diet, and from $0.68 \pm 0.17$ to $0.79 \pm 0.21 \mathrm{mmol} /$ liter on low protein $\operatorname{diet}(p<$ 0.02 , Wilcoxon rank sum test). Rate of progression as determined by the reciprocal of $\mathrm{p}$. creatinine against time was also slower in the low protein diet group $(p<$ 0.05, ANOVA).

Body weight was maintained on regular protein intake but fell initially in the low protein group. Urinary urea excretion was lower on low protein diet after 6 months. Plasma albumin was maintained in both groups but total lymphocyte count and transferrin fell on low protein intake. Middle arm circumference and triceps skin fold were similar in both.

We concluded that dietary protein restriction is effective in retarding progression of CRF, whilst maintaining adequate nutrition.

This study did not address the question of whether the beneficial effects of the diet were due to protein restriction per se, or some other component, eg phosphate, lipids. The evidence for a role for these components has been reviewed by Klahr and co-workers (1983) who regard it as less compelling than for protein.

\section{Disorders of calcium and phosphate metabolism}

Disturbances in calcium and phosphate metabolism are an invariable consequence of chronic renal failure, and can lead to further loss of renal function. Rises in plasma phosphate concentration and calcium $\mathrm{x}$ phosphorus product may precede or coincide with elevation of the plasma creatinine. Most of the controlled studies aimed at determining whether dietary phosphorus restriction can slow the progression of renal failure have been flawed by concomitant restriction of protein intake in the low phosphorus diet. Barsotti et al. (1984), however, showed that patients on a severely restricted phosphorus diet $(6.5 \mathrm{mg} / \mathrm{kg} /$ day $)$ progressed more slowly than those with a moderately restricted phosphorus intake (12 mg/kg/day), even when both groups had a similar protein intake $(0.6 \mathrm{gm} / \mathrm{kg} /$ day). Barrientos et al. (1982) were unable to demonstrate a similar effect with restriction of absorption of phosphorus by concurrent aluminium hydroxide ingestion, although the exact diet was not specified, other than being "low protein". Hypercalcaemia can also cause acute deterioration in renal function 
and usually occurs in relation to Vitamin D or calcium supplementation.

A direct nephrotoxic effect of Vitamin D has been suggested, somewhat controversially, even in patients who do not develop hypercalcaemia or a rise in the calcium-phosphorus product (Yoshiyama et al. 1980 ; Christiansen et al. 1981). There is also controversy over whether an elevated parathormone level directly leads to renal functional deterioration, rather than acting through elevation of the calcium $\mathrm{x}$ phosphorus product. Certainly in man subtotal parathyroidectomy does not prevent the increase in rate of loss of function with Vitamin D and calcium therapy (Collier and Mitch 1980).

\section{Converting enzyme inhibitors and the kidney}

The renal effects of angiotensin converting enzyme inhibition (CEI) have been reviewed by Brunner and co-workers (1987). CEI have been reported to increase renal blood flow (RBF) under conditions of renin-angiotensin system stimulation (Navar et al. 1979 ; Nishiyama et al. 1979 ; Reubi 1984) but this is not invariably seen in the sodium replete animal (Whitworth et al. 1982a; Reubi 1984). In man captopril has been reported to increase RBF in patients with essential hypertension (De Bruyn et al. 1979 ; Reubi 1984) and normal subjects (Hollenberg et al. 1981). Meggs and Hollenberg (1980) in a review of CEI and the kidney concluded that there is little response to CEI in animals or man when the renin-angiotensin system is suppressed by high sodium intake, but with sodium restriction $\mathrm{RBF}$ is increased by $\mathrm{CEI}$.

In the normal or salt depleted kidney, GFR is usually unchanged (De Bruyn et al. 1979 ; Navar et al. 1979; Nishiyama et al. 1979 ; Meggs and Hollenberg 1980 ; Hollenberg et al. 1981; Whitworth et al. 1982a ; Reubi 1984) so that where $\mathrm{RBF}$ is increased, filtration fraction falls.

Thus in the normal kidney CEI may have little effect, but will tend to increase $\mathrm{RBF}$ where the renin-angiotensin system is activated eg salt depletion, anaesthesia. In essential hypertension CEI lower pressure and tend to increase RBF while GFR remains constant and FF falls. The effects of CEI on the stenotic kidney are very different. In the aortic constricted sodium deplete dog CEI produce very marked falls in GFR and FF (Hall et al. 1981). These effects are prevented by concurrent infusion of angiotensin II, indicating All inhibition is producing the altered renal function. In human renal artery stenosis the effects of CEI are similar and may give rise to significant renal impairment (Jackson et al. 1986b ; Johnston and Hodsman 1986). Although renal function is usually normal to clinical testing in patients with unilateral renal artery stenosis on CEI, elevated serum creatinine is seen in about a third of patients with bilateral stenosis and about two-thirds of patients with stenosis of an artery to a single kidney (Johnston and Hodsman 1986).

Converting enzyme inhibitors in patients with renal disease. CEI are very effective in lowering blood pressure in patients with primary or secondary renal 
parenchymal disease (Hamilton et al. 1981 ; Walter et al. 1982 ; Herlitz et al. 1984) and sometimes dramatically effective in controlling the hypertension, and thus renal failure, of progressive systemic sclerosis (Walter et al. 1982 ; Thurm and Alexander 1984 ; Beckett et al. 1985).

CEI are excreted by the kidney and thus are given in reduced dose (once daily) in renal impairment. Even when dosage is reduced, however, renal side effects can be a significant problem, and non-renal side effects are more of a problem (Walter et al. 1982 ; Jenkins et al. 1985).

As discussed above, CEI can precipitate acute renal failure in certain patients with renal artery stenosis (Jackson et al. 1986b ; Johnston and Hodsman 1986). Similar reversible rises in creatinine have also been reported in patients with patent renal arteries (Hooke et al. 1982 ; Beroniade 1983; Murphy et al. 1984 ; Verbeelen and Boel 1984 ; Brivet et al. 1985). Some of these cases are due to interstitial nephritis (Hooke et al. 1982 ; Reubi 1984).

First dose hypotension can be a problem with CEI (Walter et al. 1982 ; Whitworth et al. 1982c) and this can also precipitate acute renal failure (Walter et al. 1982 ; Whitworth et al. 1982c). A particular concern with CEI in CRF is the risk of precipitating hyperkalaemia (Textor et al. 1982) because of CEI induced falls in aldosterone secretion. This can be a major problem where potassium sparing diuretics are used. Membranous nephropathy and nephrotic syndrome in captopril treated patients (Prins et al. 1979) has proved to be uncommon (Kincaid-Smith et al. 1980) with widespread use of the drug in appropriate dosage.

Converting enzyme inhibitors and progression of renal disease. Numerous studies have shown that functional and structural damage in the rat remnant kidney model of CRF is ameliorated by treatment with CEI (Anderson et al. 1985 ; Jackson et al. 1986a ; Beukers et al. 1987; Meyer et al. 1987). It should be noted however that this is true of early treatment and is not the case once proteinuria and glomerulosclerosis are well established (Beukers et al. 1987).

There has been much interest in the role of CEI in preventing progression in experimental (Zatz et al. 1986) and clinical diabetic nephropathy, (Taguma et al. 1985 ; Bjorck et al. 1986; Hommel et al. 1986) and this has been discussed in previous papers. Reports are now appearing which examine the role of CEI in retarding progressive loss of renal function, independent of their effects on systemic blood pressure. Bauer et al. (1987) reported 23 patients with 'essential hypertension' treated with enalapril. Twelve of the patients had moderately impaired function initially. No information was given about renal anatomy, urinalysis or urine microscopy so it is difficult to know the aetiology of the renal impairment. Over 3 years of follow-up effective renal plasma flow (ERPF) and inulin clearance increased. The study was uncontrolled. In another study (Reams and Bauer 1986) this same group examined the effects of enalapril in a small group $(n=9)$ of patients with moderate-severe renal impairment. Over 4 
weeks treatment enalapril (given with furosemide in 3 patients) lowered pressure and increased ERPF. GFR did not change. In 5 patients studied over a further 6 months GFR and ERPF remained stable. The study was uncontrolled and previous stability of function was not mentioned. They suggested that enalapril may have a renal protective effect in patients with hypertension with moderate to severe renal insufficiency.

Mann and Ritz (1987) looked retrospectively at the change in creatinine in patients with renal failure treated with either CEI $(n=39)$ or other drugs $(n=41)$. Blood pressure at presentation and after 12 months treatment were similar but median serum creatinine rose less in the CEI group, $2.33 \mathrm{mg} / 100 \mathrm{ml}$ to $2.65 \mathrm{mg}$ / $100 \mathrm{ml}$, than in the group treated with other anti-hypertensive medication, 2.39 to $3.45 \mathrm{mg} / 100 \mathrm{ml}$. The study was retrospective but the groups were said to be comparable in age and underlying renal disease. Mann and Ritz concluded that CEI "may have specific advantages with respect to preservation of renal function in patients with renal failure. Randomized trials are needed to validate this conclusion".

In a short term uncontrolled study of lisinopril on blood pressure, proteinuria and renal function in 13 patients with renal disease of different aetiologies, Heeg and co-workers (1987), found the drug reduced proteinuria by $61 \%$, whereas previous conventional anti-hypertensive therapy had not. GFR also fell on lisinopril over the 12 week period, by $21 \%,(p<0.01)$. Lagrue and colleagues (1987) treated 10 patients with primary glomerular disease with captopril for at least 6 months in an uncontrolled study and found a significant fall in proteinuria (5.0 to $2.5 \mathrm{~g} /$ day). Mean blood pressure, s. creatinine and s. potassium were respectively $159 / 95$ and $148 / 84 \mathrm{mmHg}, 158$ and $189 \mathrm{mmol} /$ liter, and 4.1 and 4.5 $\mathrm{mmol} /$ liter before and 6 months after captopril.

Over the last 2 years we have been conducting a prospective double blind randomized study of enalapril $5 \mathrm{mg}$ with matching placebo in patients with progressive renal failure. Patients with progressive loss of renal function, of known aetiology, serum creatinine $0.25-0.60 \mathrm{mmol} / \mathrm{liter}$, are eligible for entry provided they are not on current treatment with immunosuppressive drugs or CEI and there is no clinical evidence of acute on chronic renal impairment. All patients are seen at similar intervals and blood pressure, fluid and electrolyte balance and hyperphosphatemia treated on their merits. Patients are advised to keep dietary protein intake constant and are assessed regularly by a dietician. Patients are followed for 2 years. End-points are death, commencement of dialysis or development of uraemic symptoms or signs.

It is planned to compare 6 monthly ${ }^{51} \mathrm{Cr}$ EDTA clearance and the slopes of reciprocal of serum creatinine against time using analysis of variance.

\section{Effects of other drug therapy in modifying progression}

Ibopamine, an orally active dopamine analogue, has been reported to delay 
the onset of uraemia in patients with chronic renal disease (Steofini et al. 1982). Docci and co-workers (1986) undertook an uncontrolled study in 20 patients over 6 months comparing slope of the reciprocal of serum creatinine concentration against time, before and after treatment with ibopamine. The overall rate of decline in renal function decreased significantly on drug, although maximum benefit was observed in non-glomerular diseases.

Like dopamine, ibopamine augments renal perfusion in normals and presumably causes renal hyperperfusion in patients with chronic renal failure. The authors (Docci et al. 1986) point out that these 'speculations are difficult to reconcile with the hypothesized role of haemodynamically mediated injury in the pathogenesis of progressive glomerular sclerosis'.

In a randomized study comparing patients on stable antihypertensive therapy and placebo $(n=12)$ with those on the calcium channel blocker nisoldipine $(n=$ 14), Cohen and co-workers (1987) found a decrease in rate of progression in 4 of 12 on placebo and 12 of 14 on nisoldipine. Blood pressures and protein intake were similar. Overall slope of $1 /$ s. creatinine against time decreased significantly in nisoldipine patients but not in the placebo group, although slopes were different in the two groups initially. They concluded that nisoldipine reduced rate of progression of chronic renal failure significantly in protein restricted patients already treated for hypertension and hypothesized that this may have been due to prevention of renal tissue calcium deposition.

\section{Are controlled trials necessary?}

We have reviewed some of the multiplicity of factors which can affect progression of chronic renal failure in human subjects. Given this information, we believe historical controls are not sufficient to enable firm conclusions to be drawn about the value or otherwise of any particular treatment. This point was made very clearly by Bergstrom and co-workers (1986), who demonstrated that frequency of visits, and hence quality of conventional conservative care and blood pressure control, could favorably influence progression of renal failure. These observations were made during the control period of a prospective randomized study of the effects of protein intake on progression rate. The progression rate of renal failure evaluated both from the slope of reciprocal serum creatinine and creatinine clearance against time, was about $50 \%$ lower after patients entered the control phase of the study. This difference appeared attributable, at least in part, to improved blood pressure control but not to changes in protein intake. They felt their results cast doubt on the relevance of earlier longitudinal studies of the effect of protein intake, including their own, as better care of blood pressure, fluid balance and compliance with medication might have influenced progression rather than low protein diet per se. As they concluded, this observation "has important implications for the design of .... studies in the future" (Bergstrom et al. 1986).

Certainly many questions remain to be answered. The evidence that protein 
restriction retards progression is in our view good, but the case has not been proven to the satisfaction of all workers in the field. The effects of drugs, including CEI, need to be examined in carefully controlled studies, and the interactions between protein restriction and drugs requires study both in experimental animals and in man.

As the costs of ESRF management become an increasing burden so these questions become more important not only to individual patients, but to the community as a whole.

\section{References}

1) Anderson, S., Meyer, T.W., Rennke, H.G. \& Brenner, B.M. (1985) Control of glomerular hypertension limits glomerular injury in rats with reduced renal mass. J. Clin. Invest., 76, 612-619.

2) Australian Therapeutic Trial in Mild Hypertension, Report by the Management Committee, (1980) Lancet, 1, 1261-1266.

3) Baldwin, D.S. \& Neugarten, J. (1985) Treatment of hypertension in renal disease. Am. J. Kidney Dis., 5, A57-A70.

4) Barrientos, A., Arteaga, J., Rodicio, J.L., Albarez, U.F., Alcazar, J.M. \& Ruilope, L.M. (1982) Role of the control of phosphate in the progression of chronic renal failure. Miner. Electrolyte Metab., 7, 127-133.

5) Barsotti, G., Giannoni, A., Morelli, E., Lazzeri, M., Vlamis, I., Baldi, R. \& Giovanetti, S. (1984) The decline of renal function slowed by very low phosphorus intake in chronic renal patients following a low nitrogen diet. Clin. Nephrol., 21, 54-59.

6) Bauer, J.H., Reams, G.P. \& Lal, S.M. (1987) Renal protective effect of strict blood pressure control with enalapril therapy. Arch. Intern. Med., 147, 1397-1400.

7) Bear, R.A. (1976) Pregnancy in patients with renal disease. A study of 44 cases. Obstet. Gynecol., 48, 13-16.

8) Becker, G.J., Fairley, K.F. \& Whitworth, J.A. (1985) Pregnancy exacerbates glomerular disease. Am. J. Kidney Dis., 6, 266-272.

9) Becker, G.J., Ihle, B.U., Fairley, K.F., Bastos, M. \& Kincaid-Smith, P. (1986) Effect of pregnancy on moderate renal failure in reflux nephropathy. Br. Med. J., 292, 796798.

10) Beckett, V.L., Donadio, J.V., Brennan, L.A., Conn, D.L., Osmundson, P.J., Chao, E.Y.S. \& Holley, K.E. (1985) Use of captopril as early therapy for renal scleroderma: A prospective study. Mayo Clin. Proc., 60, 763-771.

11) Bennett, W., Elzinga, L., Golper, T. \& Barry, J. (1987) Reduction of cyst volume for symptomatic management of autosomal dominant polycystic kidney disease. $J$. Urol., 137, 620-622.

12) Bergstrom, J. (1984) Discovery and rediscovery of low protein diet. Clin. Nephrol., 21, 29-35.

13) Bergstrom, J., Alvestrand, A., Bucht, H. \& Gutierrez, A. (1986) Progression of chronic renal failure in man is retarded with more frequent clinical follow-ups and better blood pressure control. Clin. Nephrol., 25, 1-6.

14) Beroniade, V. (1983) Severe side-effects of captopril in advanced chronic kidney insufficiency. Proc. EDTA, 20, 530-537.

15) Beukers, J.J.B., Van Der Wal, A., Hoedemaeker, P.J. \& Weening, J.J. (1987) Converting enzyme inhibition and progressive glomerulosclerosis in the rat. Kidney Int., 32, 794-800.

16) Birch, D.F., Fairley, K.F., Whitworth, J.A., Forbes, I.K., Fairley, J.K., Cheshire, G.R. \& Ryan, G.B. (1983) Urinary erythrocyte morphology in the diagnosis of glomerular 
haematuria. Clin. Nephrol., 20, 78-84.

17) Birkenhager, W.H. \& Shalekamp, M.A.D.H. (1976) Renal haemodynamics and renal function. In: Control Mechanisms in Essential Hypertension, Elsevier, New York, p. 46.

18) Bjorck, S., Nyberg, G., Mulec, H., Granerus, G., Herlitz, H. \& Aurell, M. (1986) Beneficial effects of angiotensin converting enzyme inhibition on renal function in patients with diabetic nephropathy. Br. Med. J., 293, 471-474.

19) Blantz, R.C., Gabbai, F., Gushwa, L.C. \& Wilson, C.B. (1987) The influence of concomitant experimental hypertension and glomerulonephritis. Kidney Int., 32, 652-663.

20) Blythe, W.B. (1985) Natural history of hypertension in renal parenchymal disease. Am. J. Kidney Dis., 5, A50-A56.

21) Brenner, B.M. (1983) Haemodynamically mediated glomerular injury and the progressive nature of kidney disease. Kidney Int., 23, 647-655.

22) Brivet, F., Roulot, D., Poitrine, A. \& Dormont, J. (1985) Reversible acute renal failure during enalapril treatment in patient with chronic glomerulonephritis without renal artery stenosis. Lancet, 1, 1512.

23) Brunner, H.R., Waeber, B. \& Nussberger, J. (1987) Renal effects of converting enzyme inhibition. J. Cardiovasc. Pharmacol., 9, S6-S14.

24) Christiansen, C., Rodbro, P., Christenen, M.S. \& Hartnack, B. (1981) Is 1, 25dihydroxy-cholecalciferol harmful to renal function in patients with chronic renal failure? Clin. Endocrinol., 15, 229-236.

25) Clive, D.M. \& Stott, J.S. (1984) Renal syndromes associated with non-steroidal anti-inflammatory drugs. N. Engl. J. Med., 310, 563-572.

26) Cockcroft, D.W. \& Gault, M.H. (1976) Prediction of creatinine clearance from serum creatinine. Nephron, 16, 31-41.

27) Cohen, D., Herzog, D., Serban, I., Gavendo, S., Kapular, S. \& Eliahou, H.E. (1987) The calcium ion blocker Nisoldipine decreased the rate of progression of chronic renal failure in man, without correlating with change in blood pressure. Nephrol. Dialysis Transplant., 2, 395. (Abstract)

28) Collier, V.U. \& Mitch, W.E. (1980) Accelerated progression of chronic renal insufficiency after parathyroidectomy. JAMA, 244, 1215-1218.

29) De Bruyn, B.J.H., Verhoeven, R.P., Boomsa, F., Man-In-t Veld, A.J., Wenting, G.J. \& Schalekamp, M.A.D.H. (1979) Long term effects of converting enzyme inhibition on systemic and renal haemodynamics, body fluid volumes and plasma noradrenaline in essential hypertension. In: Proc. of the 6th Scientific Meeting, International Society of Hypertension, Goteberg, Sweden, p. 32

30) De Crespigny, P.J.C., Becker, G.J., Ihle, B.U., Walter, N.M.A., Wright, C.A. \& Kincaid-Smith, P. (1988) Renal failure and nephrotic syndrome associated with sulindac. Clin. Nephrol., 30, 52-55.

31) Disney, A.P.S. (1987) Tenth Report of the Australia and New Zealand Combined Dialysis and Transplant Registry.

32) Docci, D., Pistocchi, E., Turci, F. \& Baldrati, L. (1986) Effect of ibopamine on the progression of chronic renal failure. Clin. Nephrol., 26, 121-124.

33) EDTA Registry Centre Survey 1985 (1987) Nephrol. Dialysis, Transplant., 2, 475487.

34) Eggers, P.W. (1988) Effect of transplantation on the medicare end-stage renal disease program. N. Engl. J. Med., 318, 223-229.

35) El-Khatib, M.T., Becker, G.J. \& Kincaid-Smith, P.S. (1987) Reflux nephropathy in 293 adults. In: Abstracts of Xth International Congress of Nephrology, London, p. 49. (Abstract)

36) Fine, L.G. (1988) Preventing the progression of human renal disease : Have retional therapeutic principles emerged? Kidney Int., 33, 116-128. 
37) Hall, J.E., Coleman, T.G., Guyton, A.C., Kastner, P.R. \& Granger, J.P. (1981) Control of glomerular filtration rate by circulating angiotensin II. Am. J. Physiol., 241, R190-R197.

38) Hamilton, D.V., Evans, D.B., Maidment, G. \& Pryor, J.S. (1981) Captopril for refractory hypertension in patients with chronic renal failure and renal transplantation. J. Royal Soc. Med., 74, 357-362.

39) Hande, K.R., Noone, R.M. \& Stone, W.J. (1984) Severe allopurinol toxicity. Am. J. Med., 76, 47-56.

40) Harrington, J.T., Sommers, S.C. \& Kassirer, J.P. (1968) Atheromatous emboli with progressive renal failure : Renal arteriography as the probably inciting factor. Ann. Intern. Med., 68, 152-160.

41) Heeg, J.E., De Jong, P.E., Van Der Hem, G.K. \& De Zeeuw, D. (1987) Reduction of proteinuria by angiotensin converting enzyme inhibition. Kidney Int., 32, 78-83.

42) Herlitz, H., Edeno, C., Mulec, H., Westberg, G. \& Aurell, M. (1984) Captopril treatment of hypertension and renal failure in systemic lupus erythematosus. Nephron, 38, 253-256.

43) Hollenberg, N.K., Meggs, L.G., Williams, G.H., Katz, J., Garnic, J.D. \& Harrington, D.P. (1981) Sodium intake and renal responses to captopril in normal man and in essential hypertension. Kidney Int., 20, 240-245.

44) Hommel, E., Parving, H-H., Mathiesen, E., Edsberg, B., Nielsen, M.D. \& Giese, J. (1986) Effect of captopril on kidney function in insulin-dependent diabetic patients with nephropathy. $B r$. Med. J., 293, 467-470.

45) Hooke, D., Walker, R.J., Walter, N.M.A., d'Apice, A.J.F., Whitworth, J.A. \& KincaidSmith, P. (1982) Repeated renal failure with use of captopril in a cystinotic renal allograft recipient. Br. Med. J., 285, 1583.

46) Hou, S.H., Grossman, D.S. \& Madias, N.E. (1985) Pregnancy in women with renal disease and moderate renal insufficiency. Am. J. Med., 78, 185-194.

47) Ihle, B., Becker, G.J., Whitworth, J.A., Charlwood, R., Kincaid-Smith, P. (1989) The effect of protein restriction on the progression of renal insufficiency. $N$. Engl. J. Med., 321, 1773-1777

48) Jackson, B., Debrevi, L., Cubela, R., Whitty, M. \& Johnston, C.I. (1986a) Preservation of renal function in the rat remanant kidney model of chronic renal failure by blood pressure reduction. Clin. Exp. Pharmacol. Physiol., 13, 319-323.

49) Jackson, B., Murphy, B.F., Johnston, C.I., Kincaid-Smith, P. \& Whitworth, J.A. (1986b) Renovascular hypertension: Treatment with the oral angiotensinconverting enzyme inhibitor enalapril. Am. J. Nephrol., 6, 1982-1986.

50) Jenkins, A.C., Dreslinski, G.R., Tadros, S.S., Groel, J.T., Fand, R. \& Herczeg, S.A. (1985) Captopril in Hypertension: Seven years later. J. Cardiovasc. Pharmacol., 7, S96-S101.

51) Johnston, C.I. \& Hodsman, G.P. (1986) Angiotensin converting enzyme inhibition and renal function in renovascular hypertension. In : The Renin-Angiotensin System. 10. The Therapeutic Use of Angiotensin Converting Enzyme Inhibitors in RenoVascular Hypertension, edited by C.I. Johnston \& J.I.S. Robertson, Gower, London, pp. 10, 27-33.

52) Kesson, A.M., Talbot, J.N. \& Gyory, A.Z. (1978) Microscopic examination of urine. Lancet, 2, 809-812.

53) Kida, H., Takeda, S., Yokoyama, H., Tomosugi, N., Abe, T. \& Hatton, N. (1985) Focal glomerulosclerosis in pre-eclampsia. Clin. Nephrol., 24, 221-227.

54) Kincaid-Smith, P.S. \& Whitworth, J.A. (1987) The Kidney: A Clinico-Pathological Study. 2nd Edition. Blackwell Scientific Publications, Oxford, Melbourne.

55) Kincaid-Smith, P., Fairley, K.F. \& Bullen, M. (1967) Kidney disease and pregnancy. Med. J. Aust., 2, 1155-1159.

56) Kincaid-Smith, P., Nanra, R.S. \& Fairley, K.F. (1970) Analgesic nephropathy : A 
recoverable form of chronic renal failure. In: Renal Infection and Renal Scarring, edited by P. Kincaid-Smith \& K.F. Fairley, Mercedes Publishing Services, Melbourne, pp. $385-400$.

57) Kincaid-Smith, P., Whitworth, J.A., Walter, N.M.A. \& Dowling, J.P. (1980) Immune complex glomerulopathy and captopril (letter). Lancet, 2, 37.

58) Klahr, S., Buerkert, J. \& Purkerson, M.L. (1983) Role of dietary factors in the progression of chronic renal disease. Kidney Int., 24, 579-587.

59) Klockars, M., Saarikoski, S., Ikonen, E. \& Kuhlback, B. (1980) Pregnancy in patients with renal disease. Acta Med. Scand., 207, 207-214.

60) Kunin, C.M. (1985) Does kidney infection cause renal failure? Ann. Rev. Med., 36, $165-176$.

61) Lagrue, G., Robeva, R. \& Laurent, J. (1987) Anti-proteinuric effect of captopril in primary glomerular disease. Nephron, 46, 99-100.

62) Lindeman, R.D., Tobin, J.D. \& Shock, N.W. (1984) Association between blood pressure and the rate of decline of renal function with age. Kidney Int., 26, 861-868.

63) Llach, F., Papper, S. \& Massry, S.G. (1980) The clinical spectrum of renal vein thrombosis: Acute and chronic. Am. J. Med., 69, 819-827.

64) MacGregor, G.A., Jones, N.F., Barraclough, M.A., Wing, A.J. \& Cranston, W.I. (1973) Ureteric stricture with analgesic nephropathy. Br. Med. J., 2, 271-272.

65) Mackay, E.V. (1963) Pregnancy and renal disease. A ten year survey. Aust. NZ. J. Obstet. Gynaecol., 3, 21-34.

66) Mann, J. \& Ritz, E. (1987) Preservation of kidney function by use of converting enzyme inhibitors for control of hypertension. Lancet, 2, 622.

67) Maschio, G., Oldrizzi, L., Rugiu, C., Valvo, E., Lupo, A., Loschiavo, C., Tessitore, N., Fabris, A., Gammaro, L. \& Panzetta, G. (1987) Factors affecting progression of renal failure in patients on long term dietary protein restriction. Kidney Int., 32, S49-S52.

68) Meggs, L.G. \& Hollenberg, N.K. (1980) Converting enzyme inhibition and the kidney. Hypertension, 2, 551-557.

69) Meyer, T.W., Anderson, S., Rennke, H.G. \& Brenner, B.M. (1987) Reversing glomerular hypertension stabilizes established glomerular injury. Kidney Int., 31, 752-759.

70) Mitch; W.E., Walser, M., Buffington, G.A. \& Lemann, J. (1976) A simple method of estimating progression of chronic renal failure. Lancet, 2, 1326-1328.

71) Mitcheson, H.D., Williams, G. \& Castro, J.E. (1977) Clinical aspects of polycystic disease of the kidneys. Br. Med. J., 1, 1196-1199.

72) Mogensen, C.E. (1982) Long term anti-hypertensive treatment inhibiting progression of diabetic nephropathy. $B r . M e d . J ., 283,685-688$.

73) Morgan, T., Wilson, M., Johnston, W., Clunie, G.J. \& Gordon, R. (1974) Restoration of renal function by arterial surgery. Lancet, 1, 653-656.

74) Mowbray, J.F., Kapoor, A., Porter, K.A. \& Peart, W.S. (1980) Significance of haematuria in hypertensive patients. Lancet, 1, 231-233.

75) Murphy, B.F., Whitworth, J.A. \& Kincaid-Smith, P. (1984) Renal insufficiency with combinations of angiotensin converting enzyme inhibitors and diuretics. $B$ r. Med. J., 288, 844-845.

76) Navar, L.G., LaGrange, R.A., Bell, P.D., Thomas, C.E. \& Ploth, D.W. (1979) Glomerular and renal haemodynamics during converting enzyme inhibition (SQ 20 881 ) in the dog. Hypertension, 1, 371-377.

77) Neugarten, J., Feiner, H.D., Schacht, R.G., Gallo, G.R. \& Baldwin, D.S. (1982) Aggravation of experimental glomerulonephritis by superimposed clip hypertension. Kidney Int., 22, 257-263.

78) Nishiyama, K., Takeda, T., Nakamura, Y., Ishii, M., Matsuoka, H., Goto, A., Kimura, K., Hira, M. \& Murao, S. (1979) The effect of angiotensin converting enzyme inhibition on regional blood flow in salt depleted and salt loaded normotensive conscious rats. Jpn. Heart J., 20, 367-373. 
79) Ogden, D.A. (1983) Consequences of renal donation in man. Am. J. Kidney Dis., 11, 501-511.

80) Okuda, S., Onoyama, K., Fujimi, S., Oh, Y., Nomoto, K. \& Omae, T. (1983) Influence of hypertension on the progression of experimental autologous immune complex nephritis. J. Lab. Clin. Med., 101, 461-471.

81) Oldrizzi, L., Rugiu, C., Valvo, E., Lupo, A., Loschiavo, C., Gammaro, L., Tessitore, N., Fabris, A., Panzetta, G. \& Maschio, G. (1985) Progression of renal failure in patients with renal disease of diverse etiology on protein-restricted diet. Kidney Int., 27, 553557.

82) Orofino, L., Quereda, C., Lamas, S., Orte, L., Gonzalo, A., Mampaso, F. \& Ortuno, J. (1987) Hypertension in primary chronic glomerulonephritis. Analysis of 288 biopsied patients. Nephron, 45, 22-26.

83) Parving, H-H., Andersen, A.R., Smidt, U.M. \& Svendsen, P.A. (1983) Early aggressive treatment reduces rate of decline in kidney function in diabetic nephropathy. Lancet, 1, 1175-1178.

84) Pohl, J.E.F., Thurston, H. \& Swales, J.D. (1974) Hypertension with renal impairment: Influence of intensive therapy. Q.J. Med., 18, 569-581.

85) Prins, E.J., Hoorntje, S.J., Weening, J.J. \& Donker, A.J.M. (1979) Nephrotic syndrome in patients on captopril. Lancet, 2, 306-307.

86) Reams, G.P. \& Bauer, J.H. (1986) Effect of enalapril in subjects with hypertension associated with moderate to severe renal dysfunction. Arch. Intern. Med., 146, 21452148.

87) Reubi, F.C. (1960) The late effects of hypotensive drug therapy on renal functions of patients with essential hypertension. In : Essential Hypertension, edited by K.D. Bock \& P. Cottier, Springer-Verlag, Berlin, pp. 317-331.

88) Reubi, F.C. (1984) Captopril and renal function. Contrib. Nephrol., 43, 159-170.

89) Robitaille, P., Mongeau, J.-G., Lortie, L. \& Sinnassamy, P. (1985) Long-term follow-up of patients who underwent unilateral nephrectomy in childhood. Lancet, 1, 1297-1299.

90) Rutherford, W.E., Blondin, J., Miller, J.P., Greenwalt, A.S. \& Vavra, J.D. (1977) Chronic progressive renal disease: Rate of change of serum creatinine concentration. Kidney Int., 11, 62-70.

91) Schrier, R.W. \& Gottschalk, C.W. (1988) Nephrotoxin induced diseases of the kidney. In: Diseases of the Kidney. 4th edition, edtid by R.W. Schrier \& C.W. Gottschalk, Little Brown, Boston, p. 1137.

92) Schwartz, W.B., Hurwit, A. \& Ettinger, A. (1963) Intravenous urography in the patient with renal insufficiency. N. Engl. J. Med., 269, 277-283.

93) Shimamatsu, K., Onoyama, K., Harada, A., Kumagai, H., Hirakata, H., Mishima, C., Inenaga, T., Fujimi, S., Fujishima, M. \& Omae, T. (1985) Effect of blood pressure on the progression rate of renal impairment in chronic glomerulonephritis. J. Clin. Hypertens., 3, Suppl. 1, 239-244.

94) Steofini, S., Docci, D., Vangelista, A., Mosconi, G., Coli, L. \& Prandini, R. (1982) Long term treatment of chronic renal insufficiency with ibopamine (SB 7505), a new orally active dopamine-related drug. Clin. Nephrol., 18, 168-172.

95) Taguma, Y., Kitamoto, Y., Futaki, G., Ueda, H., Monma, H., Ishizaki, M., Takahashi, H., Sekino, H. \& Sasaki, Y. (1985) Effect of captopril on heavy proteinuria in azotemic diabetics. N. Engl. J. Med., 313, 1617-1620.

96) Taylor, J., Novak, R., Christiansen, R. \& Sorensen, E.T. (1978) Focal sclerosing glomerulopathy with adverse effets during pregnancy. Arch. Intern. Med., 138, 16951696.

97) Textor, S.C., Bravo, E.L., Fouad, F.M. \& Tarazi, R.C. (1982) Hyperkalaemia in azotemic patients during angiotensin converting enzyme inhibition and aldosterone reduction with captopril. Am. J. Med., 73, 719-725. 
98) Thurm, R.H. \& Alexander, J.C. (1984) Captopril in the treatment of scleroderma renal crises. Arch. Intern. Med., 144, 733-735.

99) Torres, V.E., Malek, R.S. \& Svensson, J.P. (1983) Vesicoureteral reflux in the adult II. Nephropathy, hypertension and stones. J. Urol., 130, 41-44.

100) Vendemia, F., Fornasieri, A., Velis, O., Baroni, M., Scarduelli, B. \& D'Amico, G. (1981) Different prevalence rates of hypertension in various reno-parenchymal diseases. In: Secondary Forms of Hypertension: Current Diagnosis and Management, edited by M.D. Blaufox \& C. Bianchi, Grune \& Stratton, New York, pp. 89-94.

101) Verbeelen, D.L. \& de Boel, S. (1984) Reversible acute on chronic renal failure during captopril treatment. Br. Med. J., 289, 20-21.

102) Viberti, G.C., Bilous, R.W., MacKintosh, D., Bending, J.J. \& Keen, H. (1983) Long term correction of hyperglycemia and progression of renal failure in insulin dependent diabetes. Br. Med. J., 286, 598-602.

103) Walter, N.M.A., Whitworth, J.A. \& Kincaid-Smith, P. (1982) Clinical experience with the angiotensin converting enzyme inhibitor captopril. Clin. Exp. Pharmacol. Physiol., 9, Suppl. 7, 117-121.

104) Whitworth, J.A., Hammond, T.G., Stewart, K.W., Mason, R.T., Schneider, E.G., Denton, D.A., Coghlan, J.P. \& Scoggins, B.A. (1982a) Effects of converting enzyme inhibition with captopril on renal function in normal and ACTH treated sheep. Clin. Exp. Pharmacol. Physiol., 9, 505-509.

105) Whitworth, J.A., Kincaid-Smith, P. \& Fairley, K.F. (1982b) The outcome of pregnancy in mesangial IgA nephropathy. In: Proceedings of Second Congress of the International Society for the Study of Hypertension in Pregnancy, edited by M.B. Sammour, E.M. Symonds, P. Zuspan \& E.L. Tomi, Ains Shams University Press, Cairo, pp. 403-408.

106) Whitworth, J.A., Walter, N.M.A. \& Kincaid-Smith, P. (1982c) "First dose" effect of captopril. Aust. NZ. J. Med., 12, 325-326.

107) Yoshiyama, N., Akiba, T., Matsui, N., Iwamato, H., Ogura, M., Nakagawa, S. \& Takeuchi, J. (1980) Deterioration of renal function in non-dialytic uraemics caused by $1 \mathrm{alpha}(\mathrm{OH}) \mathrm{D}_{3}$ which was not attributable to hypercalcaemia. Proc. E.D.T.A., 17, 569-574.

108) Yu, S.H., Whitworth, J.A. \& Kincaid-Smith, P. (1986) Malignant hypertension: Aetiology and outcome. Clin. Exp. Hypertens., A8, 1211-1230.

109) Zatz, R., Dunn, B.R., Meyer, T.W., Anderson, S., Rennke, H.G. \& Brenner, B.M. (1986) Prevention of diabetic glomerulopathy by pharmacological amelioration of glomerular capillary hypertension. J. Clin. Invest., 77, 1925-1930.

110) Zollinger, H. (1966) Niere und ableitende Harnwege. In: Spezielle Pathologische Anatomie, Vol. 3, edited by W. Doerr \& E. Vehlinger, Springer-Verlag, New York, p. 577. 